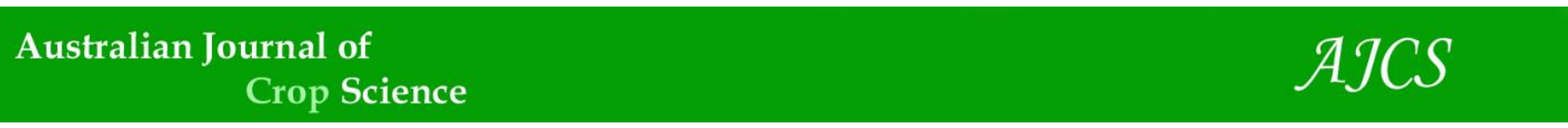

AJCS 13(03):328-334(2019)

ISSN:1835-2707

doi: To be issued soon

\title{
Soil coverage, phytomass production and, nutrient accumulation in maize and legumes intercropping system
}

\section{Antonio Nolla ${ }^{1}$; Ivo Jucksh ${ }^{2}$; João Henrique Castaldo ${ }^{3}$. Ramon Costa Alvarenga ${ }^{4}$; Liovando Marciano da Costa $^{5}$, Carla Raquel da Silva Damy ${ }^{6}$, Laudelino Vieira da Mota Neto ${ }^{7}$}

${ }^{1}$ Professor, Universidade Estadual de Maringá - Departamento de Ciências Agrárias, Estrada da Paca S/N, Umuarama - PR, Brazil, ZIP Code: 87502-000, nolla73@hotmail.com

${ }^{2}$ Professor, Universidade Federal de Viçosa - Departamento de Solos, ivo@ufv.br

${ }^{3}$ Professor, Universidade Estadual de Maringá - Departamento de Ciências Agrárias, Estrada da Paca S/N, Umuarama - PR, Brazil, ZIP Code: 87502-000, jhcastaldo@bol.com.br *** Author for contact.

${ }^{4}$ Researcher, Embrapa Milho e Sorgo, Rod MG 424 Km 45, Sete Lagoas - MG, Brazil, Zip Code: 35701-970 ramon.alvarenga@embrapa.br

${ }^{5}$ Professor, Universidade Federal de Viçosa - Departamento de solos, Av. Peter Henry Rolfs, S/N, Viçosa - MG, Brazil, Zip Code: 36570-900, liovandomc@yahoo.com.br

${ }^{6}$ Master Degree, Universidade Estadual de Maringá - Departamento de Ciências Agrárias, Estrada da Paca S/N, Umuarama - PR, Brazil, ZIP Code: 87502-000, motaneto@hotmail.com

${ }^{7}$ Academic, Universidade Estadual de Maringá - Departamento de Ciências Agrárias, Estrada da Paca S/N, Umuarama - PR, Brazil, ZIP Code: 87502-000, motaneto@hotmail.com

\section{Abstract}

The maize intercropped with legume cover crops are used at low technological agriculture, due it's potential to suppress weeds, recycle nutrients, and cover the soil. Weeds suppression it is important due to its competition effect on the commercial crops. The nutrient recycling it is important due to the low fertilizer use on low technological agriculture. The soil cover it is important to prevent the erosion and reduce the nutrients leaching. All those positive effects can be influenced due to the cultivated species on the consortium. This study aimed to evaluate the soil coverage, the phytomass production and, the accumulation of nutrients by plants in a maize and legume cover crops intercropping system. The experiment consisted of rustic maize "Caiano de Sobrália" variety, intercropped with Brazilian velvet bean, black mucuna, lablab-bean and pigeon pea; a control treatment (sole maize culture) was added. The maize was sown on the experiment; $64 \mathrm{DAE}$, the legumes were sowed. The soil cover rates were evaluated at $0,64,84,120$, and 144 DAE. The corn grains were harvested at $120 \mathrm{DAE}$, resulting in the corn grain yields. The remaining portion of maize and entire legume cover crop plants were sampled at $144 \mathrm{DAE}$, when the accumulation of dry mass and nutrient were measured. The consortium system did not affect the corn grains yield and, the soil cover rate provided by maize plants. The black mucuna had the greatest weeds suppression and, nutrient accumulation among the legumes cover crops evaluated.

Keywords: Legume cover crops, organic maize, soil conservation, weeds. Abreviation: DAE_days after the emergence of the maize plants

Introduction

The conservationist agriculture system has practices that delay the soil degradation process, caused by erosion and nutrient leaching, maintain the soil covered on the most part of the time, also accumulate biomass over the soil and recycle nutrients, turning that system, a desirable alternative to the sustainable farming. The critical period of soil exposure from the impact of raindrops, occurs between soil preparation and 30-60 days after sowing (DAS) the crops, to prevent that, the species cultivated should preferably have a rapid growth rate and, good soil coverage capacity, reducing, therefore, the erosion problems (Leite et al., 2009). To maintain the soil quality using a low-tech farming system, the intercropping system, which uses grasses, and legumes cover crop can be used, providing soil conservation and positive economic return to the farmer. However, the intercropping system should be used by technical criteria, preventing the legume cover crops to compete with the commercial crop, which can result in lower crop yields. Through that, it is recommended to seed these legumes after the critical period of competition with the main crop, which occurs, on maize, up to 45 days after the emergence (DAE) of the plants, matching the flowering period of maize plants (Kozlowski, 2002). That way, the soil 
cover effect provided by the legumes can reduce the development of weeds, without compromising the yield of the main crop. The maize is used in the consortium mainly, because of its ground coverage capacity, the favorable architecture and aggressive root system (Risso et al., 2009). The green fertilization, performed by the legumes, intercropped, results in higher corn grain yields, the jack beans (Canavalia ensiformis) (Heinrichs et al., 2002) and, Brazilian jack-beans (Canavalia brasiliensis) (Carvalho et al., 2011) has already proved that fertilization potential. The legume species that can be used along with the maize, in an intercropping system, are vast, highlighting jack beans, cowpea (Vigna unguiculata), pigeon pea (Cajanus cajan), lablab-beans (Lablab purpureum) and the gray (Mucuna pruriens), black (Mucuna aterrima) and dwarf (Mucuna deeringiana) mucunas (Castro et al., 2015). The legume cover crops used in a consortium, in addition to increasing the soil cover, decreasing the risk of erosion, can also provide nutrients to the soil solution, especially nitrogen, due to the symbiosis of those species with bacteria of the genre Rhizobium, reducing the need for nitrogen fertilization to the crops (Chagas-Júnior et al., 2012). However, the cover crops compete with the main crop, on intercropped system, at different scales, depending on the humidity, air, light, and nutrients available. One of the legume cover crops species that has been highlighted on the consortiums, due to its soil cover rate speed, is the black mucuna, which can fully cover the soil after only 60 DAS (Favero, 2001; Recalde et al., 2015).

Some authors had suggested the jack beans, in addition to the increase in grain yields effect, cover the soil efficiently (Padovan et al., 2011;. Perin et al., 2007, Favero et al., 2001), which can cover $25 \%$ of the soil, only at 15 DAE and, can reach $90 \%$ of soil cover, at only 75 DAE (Carvalho et al., 2013), turning it in the legume cover crop, with the highest soil coverage, and consequently, the greater potential of the water erosion control (Cardoso et al., 2012).

The weed plants, that emerge spontaneously on the field, are known for their harmful effect on commercial crops, because of their competition effect on the commercial crop plants development factors (Balbinot Junior et al., 2005). Even though this results in reduced yields of crops, in an intercropping system, the weeds can be important for the sustainability of the system, due to the accumulation of dry mass, which can also provide ground coverage with their residues and, the nutrient recycling, contributing, for soil conservation and its nutrients composition. Thus that, it is needed to select the species with the greatest potential use in an intercropping system with maize.The study was conducted to evaluate the corn grain yields, the ground coverage rate, the accumulation of dry mass and nutrients, of a rustic maize and several legume cover crops, in an intercropping system, and their interaction with weeds.

\section{Results and Discussion}

\section{Ground coverage by maize, legumes cover crops and weeds}

The maize presented, throughout its cycle, a similar ground cover, no matter the intercropped legumes cover crop used.
The maximum coverage rate was observed between 64 and 84 days after emergence (DAE), which matches the flowering period and, the early grain filling. After that stage, the coverage rate decreased, with the advance of the development of maize, passing trough the senescence period to the grain harvest period, wich occurred at $120 \mathrm{DAE}$ (Fig. 1). At the critical period of competition, near $45 \mathrm{DAE}$, the maize had only competition with weeds. This competition affected the development of maize through this phase. It was noted that the black velvet - maize consortium (Fig. 1A) and control (Fig. 1F) had a slightly lower ground coverage rate achieved by corn, below $40 \%$. In contrast, these treatments showed the highest ground cover by weeds. This fact demonstrates the reduction in corn development capacity, with the intensified competition from weeds and legumes with higher cover rate (Chiovato et al., 2007).

Even 64 DAE of the maize, the ground cover by weeds did not differ among treatments, because of the pressure of the maize competition, evaluated by the ground coverage rate, which was not at the maximum point yet (Fig. 1). Thus that, the conditions for the development of weeds were more favorable. However, with the development of maize, its suppressive effect also increased. Between 64 and 84 DAE of the maize, there was a reduction in covering rate of weeds, as a result of the performed plowing, for the sowing the legumes (64 DAE of the maize). Although, even without the needing of the plowing and the seeding processes, the control treatment was subjected to the same processes.

After 84 DAE of maize plants, there was a great differentiation between the effects analyzed. In addition to the reduction in the suppressive effect of maize due to the advancement of its senescence, the legumes had already established and started an intensive development.

The development and growth of legumes cover crop species, resulted in different suppressive effect over the weeds, depending on their adaptability to the consortium conditions. At maize + black mucuna intercrop, there was a lower initial muffling effect and suppression of weeds (Fig. $1 \mathrm{~A})$, because the legume had slow initial development, but after 84 days, the ground cover rate by black mucuna greatly increased, reaching $85 \%$ at 144 DAE of maize, agreeing to results obtained by Queiroz et al. (2010), Erasmus et al. (2004) and Favero et al. (2000).

Although the increase in daily coverage rate (Fig. 2), expressed in $\%$ day $^{-1}$, it's a relative measure, because the increase is not constant during the time; it shows the differences among the legumes. This increase obtained in the treatments with black mucuna was 1.06, significantly higher than the other legumes cover crop tested. Because of that, its was the only legume that significantly reduced the development of weeds (Fig. 1). This greater ground cover speed of black mucuna observed, corroborating the results obtained by Recalde et al. (2015) where it completely covered the ground, reducing the weeds cover up to $343 \%$, in comparison with control. The black mucuna adapted well to the consortium with maize, even sown after the corn 
Table 1. Corn grain yield, dried phytomass production and, nutrient content of maize, legume cover crops and, weeds on the evaluated consortiums.

\begin{tabular}{|c|c|c|c|c|c|c|c|c|c|c|c|c|c|}
\hline \multirow[t]{2}{*}{ Treatment } & \multicolumn{3}{|c|}{$\begin{array}{lr}\text { Corn } & \text { grainDried } \\
\text { yield } & \text { phytomass }\end{array}$} & $\mathrm{N}$ & \multicolumn{2}{|l|}{$\mathrm{P}$} & \multicolumn{2}{|l|}{ K } & $\mathrm{Ca}$ & \multicolumn{3}{|c|}{$\mathrm{Mg}$} & \\
\hline & \multicolumn{12}{|c|}{ Maize plants } & \\
\hline Lablab-bean & $2,020 \mathrm{a}$ & 4,810 & a & 40.88 & & 1.92 & & 43.77 & & 10.58 & & 8.66 & \\
\hline Black mucuna & $2,069 \mathrm{a}$ & 4,927 & a & 41.88 & & 1.97 & & 44.83 & & 10.84 & & 8.87 & \\
\hline Brazilian jack beans & $1,917 \mathrm{a}$ & 4,564 & a & 38.79 & & 1.83 & & 41.53 & & 10.04 & & 8.21 & \\
\hline Jack beans & 1,659 a & 3,950 & a & 33.57 & & 1.58 & & 35.94 & & 8.69 & & 7.11 & \\
\hline Pigeon pea & $1,652 \mathrm{a}$ & 3,933 & a & 33.43 & & 1.57 & & 35.79 & & 8.65 & & 7.08 & \\
\hline \multirow[t]{2}{*}{ Control } & $2,129 \mathrm{a}$ & 5,068 & a & 43.08 & & 2.03 & & 46.12 & & 11.15 & & 9.12 & \\
\hline & \multicolumn{12}{|c|}{ Legume cover crops } & \\
\hline Lablab-bean & ---- & 880 & c & 22.18 & c & 2.73 & $\mathrm{~b}$ & 9.68 & $\mathrm{bc}$ & 10.12 & $\mathrm{c}$ & 1.76 & c \\
\hline Black mucuna & ---- & 5,979 & a & 153.65 & a & 12.56 & a & 78.32 & a & 58.59 & $a$ & 10.76 & $a$ \\
\hline Brazilian jack beans & --- & 718 & c & 17.80 & c & 1.44 & $b$ & 6.24 & bc & 17.15 & $\mathrm{bc}$ & 2.01 & c \\
\hline Jack beans & --- & 1,904 & $b$ & 55.02 & $b$ & 4.19 & $b$ & 23.23 & $b$ & 31.03 & $\mathrm{~b}$ & 5.14 & $b$ \\
\hline \multirow[t]{2}{*}{ Pigeon pea } & ---- & 295 & c & 6.97 & c & 0.65 & $b$ & 2.72 & c & 2.01 & C & 0.50 & c \\
\hline & \multicolumn{12}{|l|}{ Weeds } & \\
\hline Lablab-bean & ---- & 1,758 & $a b$ & 30.60 & $a b$ & 4.20 & $a b$ & 36.60 & $\mathrm{a}$ & 18.30 & $a$ & 4.00 & a \\
\hline Black mucuna & ---- & 1,060 & $b$ & 14.40 & $b$ & 2.10 & $b$ & 18.80 & $b$ & 9.70 & $a$ & 2.20 & $a$ \\
\hline Brazilian jack beans & ---- & 1,612 & $a b$ & 28.70 & $a b$ & 4.20 & $a b$ & 35.30 & a & 15.00 & $a$ & 3.50 & $a$ \\
\hline Jack beans & ---- & 2,150 & $a$ & 35.70 & $a b$ & 4.90 & $a b$ & 39.80 & a & 17.40 & $\mathrm{a}$ & 4.90 & $a$ \\
\hline Pigeon pea & ---- & 2,208 & a & 35.80 & $a$ & 5.10 & $a$ & 42.00 & a & 15.50 & $a$ & 4.40 & a \\
\hline \multirow[t]{2}{*}{ Control } & ---- & 2,682 & a & 39.80 & $a$ & 5.70 & $a$ & 41.00 & a & 18.20 & $\mathrm{a}$ & 5.80 & a \\
\hline & \multicolumn{12}{|l|}{ Total } & \\
\hline Lablab-bean & ---- & 7,448 & $b$ & 93.66 & $b$ & 8.85 & $b$ & 90.05 & $b$ & 33.23 & $\mathrm{~b}$ & 14.42 & $b$ \\
\hline Black mucuna & ---- & 11,966 & $a$ & 209.93 & a & 16.63 & $a$ & 141.95 & a & 73.22 & $a$ & 21.83 & a \\
\hline Brazilian jack beans & --- & 6,894 & $b$ & 85.29 & $b$ & 7.47 & $b$ & 83.07 & $b$ & 36.71 & $\mathrm{~b}$ & 13.72 & $b$ \\
\hline Jack beans & --- & 8,004 & $a b$ & 124.29 & $a b$ & 10.67 & $a b$ & 98.97 & $b$ & 52.38 & $a$ & 17.15 & $a$ \\
\hline Pigeon pea & ---- & 6,436 & $b$ & 76.20 & $b$ & 7.32 & $b$ & 80.51 & $b$ & 21.44 & $\mathrm{~b}$ & 11.98 & $b$ \\
\hline Control & ---- & 7,750 & $b$ & 82.88 & $b$ & 7.73 & $b$ & 87.12 & $b$ & 23.27 & $\mathrm{~b}$ & 14.92 & b \\
\hline
\end{tabular}

Table 2. Chemical and physical analysis of soil $(0-10 \mathrm{~cm})$ on treatments, at the experimental installation phase.

\begin{tabular}{|c|c|c|c|c|c|c|}
\hline Soil atributes & Lablab-bean & Black Mucuna & $\begin{array}{l}\text { Brazilian jack } \\
\text { beans }\end{array}$ & Jack beans & Pigeon pea & Control \\
\hline $\mathrm{Ca}^{2+}\left(\mathrm{cmol}_{\mathrm{c}} / \mathrm{dm}^{3}\right)$ & 5.47 & 5.25 & 5.74 & 4.97 & 5.18 & 5.21 \\
\hline $\mathrm{Mg}^{2+}\left(\mathrm{cmol}_{\mathrm{c}} / \mathrm{dm}^{3}\right)$ & 0.68 & 0.64 & 0.80 & 0.63 & 0.61 & 0.68 \\
\hline$P\left(\mathrm{mg} / \mathrm{dm}^{3}\right)$ & 12.42 & 9.28 & 9.14 & 8.87 & 6.67 & 8.15 \\
\hline $\mathrm{K}^{+}\left(\mathrm{cmol}_{\mathrm{c}} / \mathrm{dm}^{3}\right)$ & 0.09 & 0.10 & 0.12 & 0.08 & 0.08 & 0.10 \\
\hline $\mathrm{S}\left(\mathrm{cmol}_{\mathrm{c}} / \mathrm{dm}^{3}\right)$ & 6.24 & 5.99 & 6.66 & 5.68 & 5.87 & 5.99 \\
\hline $\mathrm{Al}^{3+}\left(\mathrm{cmol}_{\mathrm{c}} / \mathrm{dm}^{3}\right)$ & 0.02 & 0.02 & 0.01 & 0.02 & 0.02 & 0.02 \\
\hline $\mathrm{H}^{+}+\mathrm{Al}^{3+}\left(\mathrm{cmol}_{\mathrm{c}} / \mathrm{dm}^{3}\right)$ & 4.38 & 4.72 & 4.24 & 4.76 & 4.78 & 4.69 \\
\hline $\mathrm{BS}^{1}(\%)$ & 59 & 56 & 61 & 54 & 55 & 56 \\
\hline $\mathrm{pH}\left(\mathrm{H}_{2} \mathrm{O}\right)$ & 6.16 & 6.06 & 6.12 & 6.07 & 6.08 & 6.10 \\
\hline $\mathrm{pH}(\mathrm{KCl})$ & 5.05 & 4.96 & 5.16 & 5.00 & 4.95 & 5.00 \\
\hline Clay (\%) & 19.23 & 19.55 & 17.90 & 19.57 & 19.18 & 18.50 \\
\hline $\mathrm{OM}^{2}(\mathrm{~g} / \mathrm{kg})$ & 23.77 & 23.30 & 24.18 & 23.43 & 22.87 & 23.45 \\
\hline
\end{tabular}



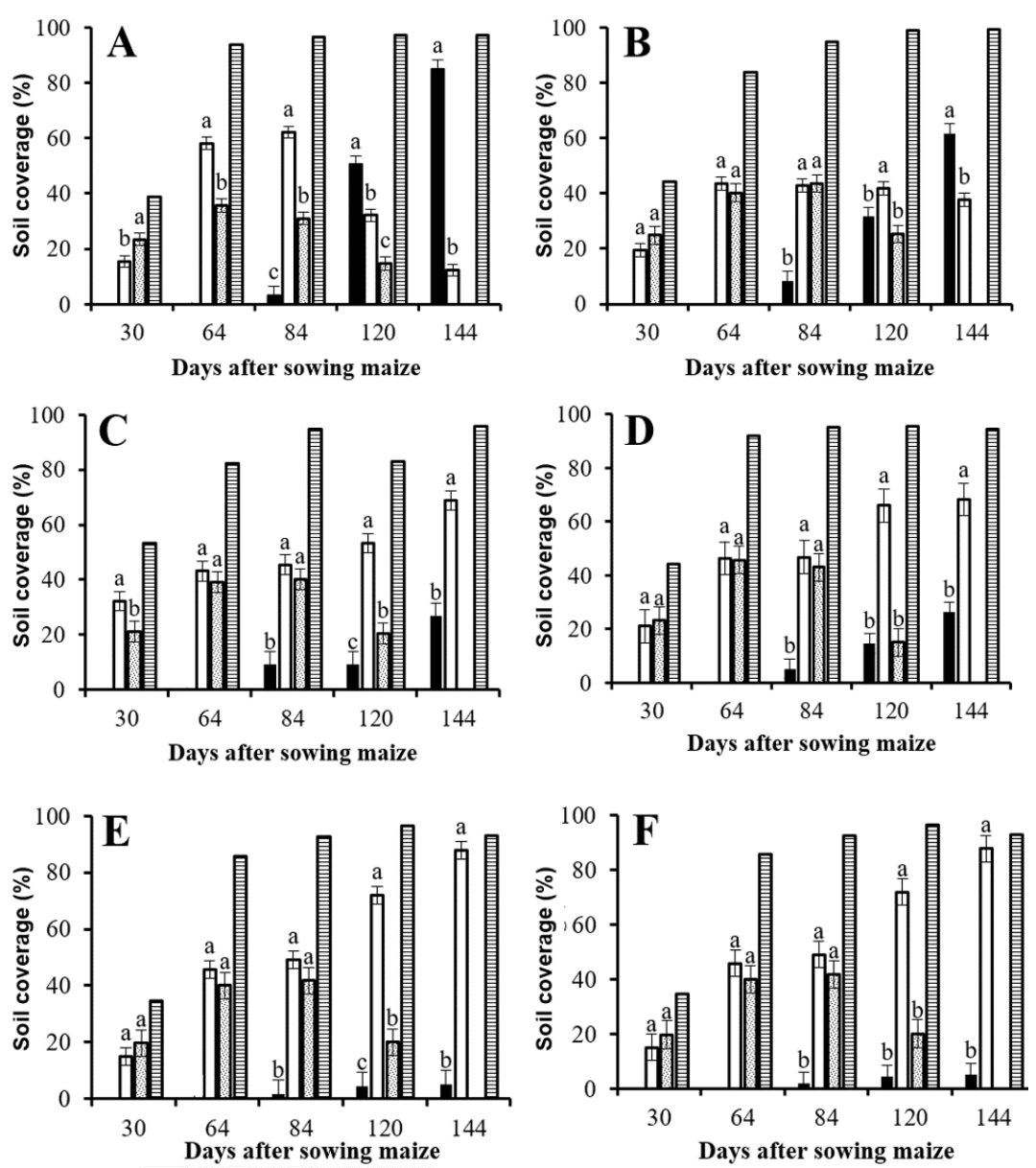

- Legume cover crops $\square$ Weeds $\square$ Maize 目Total consortium

Fig 1. Soil cover rate by the consortiums composed by maize, legumes cover crops and, weeds. Where (A) Mucuna aterrima, (B) Canavalia ensiformis, (C) Canavalia brasiliensis, (D) Dolichos lablab, (E) Cajanus cajan and, (F) control without legume. Same letters, on the same evaluation date, doesn't differ by Tukey test at $p<0.05$ of error.

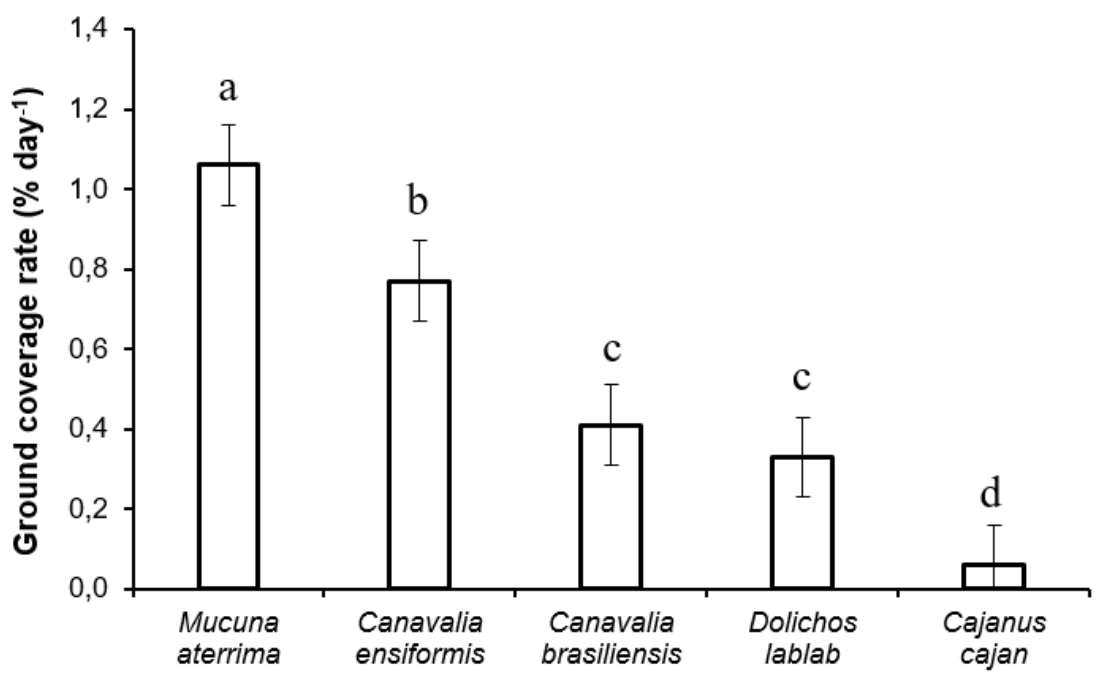

Fig 2. Relative soil coverage rate $\left(\%\right.$ day $\left.^{-1}\right)$ by the legume cover crops. Same letters, doesn't differ by Tukey test at $p<0.05$ of error. 
grain filling was started and, the soil has a high spontaneous infestation. According to that, the black mucuna was the legume cover crop with the greatest potential to control weeds.

The intercropping of jack beans (Canavalia ensiformis) + corn, stabilized the soil coverage rate by weeds, a little over $40 \%$ (Fig. 1B), demonstrating the intermediate ability suppression of the jack beans as a legume cover crop. The jack bean plants increased the soil cover from $8 \%$ at 84 DAE of maize to $61.63 \%$ at 144 DAE of maize, verifying that its daily coverage ratio was 0.77 . This confirms the potential for a faster growth rate of the jack beans after the initial period of establishment, in agreement to the results obtained by Favero et al. (2001), Padovan et al. (2011) and Recalde et al. (2015).

The Brazilian jack-beans and lablab-bean presented a final rate ground cover $30 \%$ (Fig. 1C) and $24 \%$ (Fig. 1D), respectively, much lower than the jack beans and, especially the black mucuna, agreeing to the results obtained by Teodoro et al. (2014). This indicates a lower adaptability of these legumes to the consortium conditions, which were established when the maize and spontaneous were already established and providing a greater pressure of competition to the system, corroborating with Castro and Devide (2015). As a result, the lablab-bean and the Brazilian jack-bean were both less efficient in controlling spontaneous, because the weeds continued to growth until the end of the evaluation period (Fig. 1C, Fig. 1D and Fig. 2).

Pigeon pea showed only $5 \%$ ground cover rate after $80 \mathrm{DAE}$ of maize (Fig. 1E), due to germination and emergence problems, even considering their upright growth habit and longer cycle, when compared to other legumes (Favero et al., 2001). In contrast, the spontaneous at this treatment had a similar performance to control, with soil cover rate near $90 \%$ at the end of the evaluation period. Because of the problems presented, these results should not be considered as a standard for the pigeon pea + maize intercrop system, where you can expect better performance of this legume, with a correct establishment.

Considering the total rate of soil coverage provided by the consortiums, it was observed that, at 64 DAE of maize, all consortiums presented coverage rate higher than $80 \%$ (Fig. 1). This has highlighted the benefit to the soil and water conservation, because on those conditions, the loss of soil and water, are reduced (Silva et al., 2008, Blainski et al., 2012).

\section{Corn grain yield}

The corn grain yields was very low (1,652 - 2,129 $\left.\mathrm{kg} \mathrm{ha}^{-1}\right)$, in comparison with the commercial crops of maize, that are conducted using higher technological level, where competition among plants is minimal and, the adequate supply of nutrients, is supplied, can achieve yields higher than 19,000 kg ha ${ }^{-1}$ (Caires and Mila, 2016), as does the production of dry mass (Table 1 ), however, the results considered here are for a segment of society that adopts low technological level.

These results came from different factors, that have influenced the systems. The first is the nutrient deficiency, by the recycling performed by the maize + legumes and weeds, which did not allow normal development of maize and as a result, its growth and production were adversely affected (Valadares et al., 2012). These findings do not invalidate the results achieved in this test, as they are directed to a different reality, that is, organic corn production by family farmers with no synthetic inputs and cultural practices, in agreement with results obtained by Carpentieri-Pipolo et al. (2010).

Another major factor is the competition of cereal with the weeds. As the management of the treatments had not controlled those plants, the competition with weeds was settled at the beginning of the cycle and, extended throughout the critical period of competition for maize, that goes up to 27 days after emergence of the crop (Galon et al. 2008). At this stage, there is a great accumulation of nutrients, that are responsible, in large part for the production of grain and vegetable biomass. After this critical phase (20-60 days), the maize plants continue absorbing the nutrients for some time, but it does not compromise productivity. For example, Pinho et al. (2009), demonstrated that the peak of absorption of phosphorus in maize is settled between 80 to 138 days after emergence.

\section{Legumes cover crop mass and nutrients accumulation}

Among the legumes, the black mucuna showed higher dry mass accumulation $\left(5,979 \mathrm{~kg} \mathrm{ha}^{-1}\right)$ and nutrients (153.65, 12.56 , and $78.32 \mathrm{~kg} \mathrm{ha}^{-1}$ of $\mathrm{N}, \mathrm{P}$ and, $\mathrm{K}$, respectively), confirming the highest coverage rate (up to $85 \%$ ) provided by this legume, while the consortium was developed (Fig. 1), mainly due to its creeping growth habit and aggressiveness over the weeds, confirming its played a decisive role in suppressing the weeds and accumulating higher amounts of nutrients ( $\mathrm{N}, \mathrm{P}, \mathrm{K}, \mathrm{Ca}$ and $\mathrm{Mg}$ ), compared to other legumes, in agreement with results obtained by Queiroz et al. (2010) and Erasmus et al. (2004). Additionally, the weed plants at black mucuna consortium accumulated less dry weight $\left(1,060 \mathrm{~kg} \mathrm{ha}^{-1}\right)$ and nutrients, due to the suppression effect exerted by the legume. The black mucuna contributed with at least $50 \%$ of the total dry mass and, nutrient content of the consortium (Table 1), confirming its greater adaptability for the consortium with maize and suppression of spontaneous.

The jack beans had an intermediate performance among the legumes. The dry biomass production was three times lower $\left(1,904 \mathrm{~kg} \mathrm{ha}^{-1}\right)$ than the black mucuna. On the other hand, produced twice more biomass than the lablab $\left(880 \mathrm{~kg} \mathrm{ha}^{-1}\right)$ and, Brazilian jack-beans ( $718 \mathrm{~kg} \mathrm{ha}^{-1}$ ) and, more than six times than the biomass produced by the pigeon pea $(295 \mathrm{~kg}$ $\left.\mathrm{ha}^{-1}\right)$. Also, the nutrients amount immobilized followed the same trend. Regarding the pressure to suppress the weeds, the jack beans were not more efficient compared to the lablab-bean, Brazilian jack-bans and, pigeon pea. This may have occurred because, despite the high jack beans coverage $(61.39 \%$ at 80 days of its cycle), its dry mass $(1,904$ $\left.\mathrm{kg} \mathrm{ha}^{-1}\right)$ have not been as effective in suppressing the weeds. It seems occurred by their growth habit, jack beans exercised less suppression of the weeds than other legumes because, due to its rapid initial growth, it may found more competition with maize initially. This may occur because, erect legumes and determined growth habit, as the jack beans, are less efficient controlling the native population than creeping growth habit legumes. Carvalho and Amabille (2006). 
The dry mass accumulation of the lablab-bean, Brazilian jack bean and, pigeon pea was very low $(880,718$ and, $295 \mathrm{~kg}$ ha 1 , respectively). Therefore, the fixed nutrient content for these legumes was also low ( $\mathrm{N}$ accumulation up to 22 times lower) and, the suppression of weeds was lower (up to 2.1 times higher weeds mass accumulation), compared to black mucuna. Due to the low pressure on the weeds, those plants produced more biomass $\left(2,208 \mathrm{~kg} \mathrm{ha}^{-1}\right.$ with pigeon pea), getting near to the control treatment $\left(2,682 \mathrm{~kg} \mathrm{ha}^{-1}\right)$. Under these conditions, the fixed quantity of nutrients by weeds was higher ( 35.8 and, $5.10 \mathrm{~kg} \mathrm{ha}^{-1}$ of $\mathrm{N}$ and, $\mathrm{P}$, respectively), compared to treatment with black mucuna. This poor performance of the pigeon pea can be associated with problems at the establishment of the plants, occurred in this experiment, and should be retested.

Keeping the soil covered and, dry mass production is important for contain the soil erosion and prevent the nutrient leaching. For this, it is preferred those consortiums that have a greater accumulation of dry mass and, nutrients on their plants, but not reducing the performance of the main crop. Thus that, there is some kind of balance of those characteristics on maize consortium with black mucuna, mainly for their higher dry mass and nutrients accumulation.

\section{Material and Methods}

\section{Experimental plot}

The experiment was settled at Embrapa Milho e Sorgo, located at Sete Lagoas - MG $\left(19^{\circ} 28^{\prime}\right.$ South latitude and $44^{\circ} 15^{\prime}$ 'West longitude) in a Oxisol typical soil (Santos et al., 2013). The chemical and granulometric characterization of the soil is presented in Table 2 . The soil was initially mobilized with plower followed by a leveler, at which the plant residues on the surface were incorporated.

\section{Treatments description and experimental design}

The treatments consisted of maize intercropped with the following legumes cover crops: jack beans (Canavalia ensiformis), Brazilian jack-bean (Canavalia brasiliensis), black mucuna (Mucuna aterrima), lablab-bean (Lablab purpureum) and pigeon pea (Cajanus cajan). Also, a control treatment, with maize only, was added. The treatments were installed in plots measuring $5 \times 5$ meters, and the experimental design was a randomized block design with four replications. The considered portion of plots, used to collect the data to experiment, measured $2 \times 2$ meters, with there were two lines of maize on it.

\section{Conduction of the experiment}

The rustic maize variety, called "Caiano de Sobrália" was sown at the lines, that were spaced $1 \mathrm{~m}$ each, with the final population of 50,000 plants per hectare. The legumes have been sown 64 days after the maize, on the space between the maize crop lines. The final stand of legumes were: five plants per meter of jack beans, Brazilian jack-bean and, black mucuna; seven plants per meter of lablab-bean; and, two plants per meter of pigeon pea.

\section{Data gathering}

The corn grains were harvested at 120 days after emergence, collecting them from all the ears from the considered portion of the plots; the moisture of the was measured after 24 hours with $105^{\circ} \mathrm{C}$ forced air dryer, was corrected to $13 \%$ mathematically. At 144 days after sowing the maize, the legume cover crops were sampled and the remaining plants were managed (cut off at its basis, and the residues left over the ground). For the sampling, it was used a cast framework measuring $0.5 \times 0.5 \mathrm{~m}$, which was released four times randomly in each plot. Weeds plants present in the plots were also sampled at that time, having been used the same methodology used in the collection of leguminous plants.

The ground cover rate provided by the system components was measured at 30,64, 84, 120 and, 144 days after emergence of maize, by randomly launching four times, in each plot, a $5 \times 5 \mathrm{~cm}$ string gridded framework that measures $50 \times 50 \mathrm{~cm}$, and comparing the matching grid intersections with the aboveground vegetation to total intersections of the framework.

The determination of the dry mass of the sampled plant materials was obtained submitting the sample to a forced circulation dryer at $65^{\circ} \mathrm{C}$ for 72 hours, with the results being expressed in $\mathrm{kg} \mathrm{ha}^{-1}$. After determination of the dry mass of the species in each plot, the samples were grinded in a Wiley Mill type with a later blending and homogenization, obtaining a composite sample for each material.

It was mineralized $0.2 \mathrm{~g}$ of composite samples via nitric, perchloric digestion ( $3 \mathrm{ml}$ of nitric acid: $1 \mathrm{ml}$ perchloric acid), using the resulting extract to determinate the Calcium, Magnesium, Phosphorus, Potassium and, Nitrogen contents on the plants, using the methodology described by Silva (1999).

\section{Statistical analysis}

All results were submitted to analysis of variance and means were compared by Tukey test at $p<0.05$ probability of error.

\section{Conclusions}

Development and growth characteristics of the species of legume cover crops and, their adaptability to the consortium with maize, resulted in a different suppressive effect of the weeds.

The black mucuna has a better adaptation to the consortium with the maize, even sown after the established cereal and, the soil with a high infestation of weeds, it showed the greatest potential to control the weeds and should be preferred to jack beans and the other legume cover crops tested.

\section{Acknowledgements}

To Federal Univesity of Viçosa, EMBRAPA Milho e Sorgo, and Coordenação de Aperfeiçoamento de Pessoal de Nível Superior - CAPES. 


\section{References}

Balbinot Jr AA, Bialeski M, Backes RL (2005) Épocas de manejo de plantas de cobertura do solo de inverno e incidência de plantas daninhas na cultura do milho. Agrop Cat. 18: 91-94.

Blainski É, Tormena CA, Guimarães RML, Nanni MR (2012) Qualidade física de um Latossolo sob plantio direto influenciada pela cobertura do solo. Rev Bras Cienc Solo. 36: 79-87.

Carpentieri-pípolo V, Souza A, Silva DA, Barreto TP, Garbuglio DD, Ferreira JM (2010) Avaliação de cultivares de milho crioulo em sistema de baixo nível tecnológico. Acta Sci: Agron. 32: 229-233.

Caires EF, Milla R (2016) Adubação nitrogenada em cobertura para o cultivo de milho com alto potencial produtivo em sistema de plantio direto de longa duração. Bragantia. 75: 87-95.

Cardoso DP, Silva MLN, Carvalho GJ, Freitas DAF, Avanzi JC (2012) Plantas de cobertura no controle das perdas de solo, água e nutrientes por erosão hídrica. R Bras Eng Agríc Ambiental. 16: 632-638.

Carvalho AM, Amabile RF (2006) Cerrado: Adubação verde. EMBRAPA, Brasília DF Brasil.

Carvalho AM, Souza LLP, Guimarães Jr R, Alves PCAC, Vivaldi U (2011) Cover plants with potential use for crop-livestock integrated systems in the Cerrado region. Pesq Agropec Bras. 46: 1200-1205.

Carvalho WP, Carvalho GJ, Abbade Neto DO, Teixeira LGV (2013) Desempenho agronômico de plantas de cobertura usadas na proteção do solo no período de pousio. Pesq Agropec Bras. 48: 157-166.

Castro CM, Devide ACP (2015) Cultivo orgânico de milho verde consorciado com leguminosas. Pesq \& Tecnologia. $12: 1-6$

Chagas-Júnior AF, Santos GR, Melo RCL, Oliveira AG, Vizioli B, Chagas LFB, Costa JL (2012) Effect of natural nodulation in the development of leguminous trees on soils of cerrado in Tocantins. Journal of Byotechnology and Biodiversity. 3: 38-44.

Chiovato MG, Galvão JCC, Fontanétti A, Ferreira LR, Miranda GV, Rodrigues OL, Borba NA (2007) Diferentes densidades de plantas daninhas e métodos de controle nos componentes de produção do milho orgânico. Planta Daninha. 25: 277-283.

Erasmo EAL, Azevedo WR, Sarmento RA, Cunha AM, Garcia SLR (2004) Potencial de espécies utilizadas como adubo verde no manejo integrado de plantas daninhas. Planta Daninha, 22: 337-342.

Favero C, Jucksch I, Costa LM, Alvarenga RC, Neves JCL (2000) Crescimento e acúmulo de nutrientes por plantas espontâneas e por leguminosas utilizadas para adubação verde. Rev Bras Cienc Solo. 24: 171-177.

Favero C, Jucksch I, Alvarenga RC, Costa LM (2001) Modificações na população de plantas daninhas na presença de adubos verdes. Pesq Agropec Bras, Brasília. 36: 1355-1362.

Galon L, Pinto JJO, Rocha AA, Concenço G, Silva AF, Aspiazú I, Ferreira EA, França AC, Ferreira FA, Agostinetto D, Pinho
CF (2008) Períodos de interferência de Brachiaria plantaginea na cultura do milho na região Sul do Rio Grande do Sul. Planta Daninha. 26: 779-788.

Heinrichs R, Vitti GC, Moreira A, Fancelli AL (2002) Produção e estado nutricional do milho em cultivo intercalar com adubos verdes. Rev Bras Cienc Solo. 26: 225-230.

Kozlowski LA (2002) Período crítico de interferência das plantas daninhas na cultura do milho baseado na fenologia da cultura. Planta Daninha. 20: 365-372.

Leite MHS, Couto EG, Amorim RSS, Costa EL, Maraschin L (2009) Perdas de solo e nutrientes num Latossolo Vermelho-Amarelo ácrico típico, com diferentes sistemas de preparo e sob chuva natural. Rev Bras Cienc Solo. 33: 689-699.

Padovan MP, Motta IS, Carneiro LF, Moitinho MR, Fernandes SSL (2011) Acúmulo de fitomassa e nutrientes e estádio mais adequado de manejo de Canavalia ensiformes para fins de adubação verde. Rev Bras de Agroecologia. 6: 182190.

Perin A, Bernardo JT, Santos RHS, Freitas GB (2007) Desempenho agronômico de milho consorciado com feijão-de-porco em duas épocas de cultivo no sistema orgânico de produção. Ciência e Agrotecnologia. 31: 903908.

Pinho RG, Borges ID, Pereira JLAR, Reis MC (2009) Marcha de absorção de macronutrientes e acúmulo de matéria seca em milho. Rev Bras Milho e Sorgo. 8: 157-173.

Queiroz LR, Galvão JCC, Cruz JC, Oliveira MF, Tardin FD (2010) Supressão de plantas daninhas e produção de milho-verde orgânico em sistema de plantio direto. Planta Daninha. 28: 263-270.

Recalde KMG, Carneiro LF, Carneiro DNM, Felisberto G, Nascimento JS, Padovan MP (2015) Weed suppression by green manure in an agroecological system. Rev Ceres. 62: 546-552.

Risso IAM, Guerra JGM, Ribeiro RLD, Souza CG, Espindola JAA, Polidoro JC (2008) Cultivo orgânico do milho consorciado com leguminosas para fins de adubação verde. EMBRAPA, Seropédica Rio de Janeiro Brasil.

Santos HG, Jacomine PK, Anjos LHC, Oliveira VAV, Lumbreras JF, Coelho MR, Almeida HA, Cunha TJF, Oliveira JB (2013) Sistema Brasileiro de Classificação de Solos. EMBRAPA, Brasília Distrito Federal Brasil.

Silva RF, Borges CD, Garib DM, Mercante FM (2008) Atributos físicos e teor de matéria orgânica na camada superficial de um Argissolo Vermelho cultivado com tomate sob difetentes manejos. Rev Bras Cienc Solo. 32: 2435-2441.

Silva FC (1999) Manual de análises químicas de solos, plantas e fertilizantes. EMBRAPA, Brasília Distrito Federal Brasil.

Teodoro PE, Ribeiro LP. Silva FA, Corrêa CCG, Luz Jr RAA, Torres FE (2014) Sample size to estimate biomass and productivity of Canavalia ensiformis and Dolichos lablab. Rev de Ciências Agrárias. 37: 348-353.

Valadares RV, Duarte RF, Menezes JBC, Fernandes LA, Santos LDT, Sampaio RA, Mota TC, Almeida RM (2012) Fertilidade do solo e produtividade de milho em sistemas de adubação verde no norte de Minas Gerais. Planta Daninha. 30: 505-516. 